\title{
Cementation Analysis of Algae and Marine Borer Invertebrates on Boat Wood in Ambon Coastal Water of Ambon-Indonesia
}

\author{
Dr. Hasan Tuaputty, M.Pd. \\ Department of Biology Education, Pattimura University, Ambon- Indonesia
}

\begin{abstract}
Woods have been using for marine transportation vehichles in Central Maluku that consist of various species, however, commonly are G melina moluccana Backer, Agathis alba Foxw, Inesia amboinensis Thouaes, Calophyllum inophyllum Liin. Utilizing of those woods are still limited. Determining the proper durability standards for local and fishermen uses is needed by experimental and survey reseach to provide information for mastering local fishermen knowledge based on their education levels about woods quality and marine borers. This research based on the problems were (1) to derive information about algae and marine borers species attaching on various woods that were soaked in different depths and distances from shorelines, (2) to know the effects of boating wood materials, soaking depth locations and soaking distances of shoreline towards algae cementation. (3) To gain information about the effects of boating woods species, soaking depth locations, and soaking distances of shoreline towards marine borers'abundances. Finding results of algae species and marine borers' species attaching to treated woods consist of 14 species for algae and 6 species for marine borers. Those algae species are formed by genus such Clorophyceae (7 species), Rodophyceae (3 species), and Paeophyceae (4 species). Whilist, those marine borers species are Lepas sp, Balanus balanus, Chatamalus proteus, Cellana tramoserica, Styela plicata, Crassostrea ieginica. Resulting of anava analysis is described as following. Firstly, woods species significantly leavened towards the differances of algae cementation with $P$ value $=0.000<\alpha 0.01$. The most thickness algae cementation is found in Agahtis alba Foxw and the lowest one in Calophyllum inophyllum Liin. Those all four treated woods are different each others. Secondly, soaking distances of shoreline is highly significant effects toward the differences of algae cementation that its $P$ value $=0.000<\alpha 0.01$. Algae cementation on 30 meters long in distance of shoreline is the most thickness and the lowest one is on 50 meters long. Thirdly, there are significant effects among soaking depths and algae cementation which is significantly on level $P$ value $=0.000<\alpha 0.01$. The most thickness of algae cementation is found in 1 meter soaking depth and the lowest one in 2 meters depth.
\end{abstract}

Keywords: woods species, algae cementation, marine borers' abundance

\section{Introduction}

Moluccas Province geographically has a vast sea than its land. It has territorial as large as $712.479,69 \mathrm{~km}$ squares and consists of 525 islands. Of all areas, lands only cover $5.8 \%$ of territorials and the other is sea. Most of its islands is small islands and commonly as wide as $10-2,000 \mathrm{~km}$ squares. Those islands, about 453 islands is not yet registered and most of them is around border lines. Moluccas has population about $1,200,067$ people that spread out in to 890 villages in various islands. It is about $90.7 \%$ settles in coastal areas. Its population density divided into three categories, 1,001 - 10,000 people $/ \mathrm{km}$ squares (populous), 101-1.001 people / km squares (fair), and 11-101 people / $\mathrm{km}$ squares (low), respectively. Marine and ocean development should be prioritized because $70.8 \%$ of its population rely on ocean resources and $29.2 \%$ on other resources and the other $44.57 \%$ is till under poverty that is distributed into 539 villages of 890 villages (Balitbangdal Provinsi Maluku, 2014).

Serving of marine transportation is verily needed to increase communities life standard in coastal areas due there are a lot of isolated villages that are not yet reached. It is caused by the limitation of marine transportation and less of new port development in those areas. The common marine transportation found in the areas merely are made traditionally of woods with tonnage about $10-20 \mathrm{GT}$, however, the wood quality for the transportation is till unkwon and limited. Some woods species using for boats as marine transportation at Ambon and Seram Islands are
Gmelina moluccana Backer, Agathis alba Foxw), Intsia amboinensis Thouaes, Callophyllum inophyllum Liin. Woods using for marine transportation have a highly quality which meet requirements such as tolerance toward direct weather in as long as 20 years, it has to be good condition in the water environment and resistance against to the marine borers (Tuaputty, 2008). Sjostrom (1995) stating that wood damage in water environmet caused by extractive compound of the wood that has function to protect the wood in the water undergoes degradation into the water and it is given opportunity for algae and marine borers to attach. Availability of wood boat or wood in the marine is a place for the marine algae to attach that to be food sources for marine borers. Nur (2002) explained that algae is a phytoplankton as food resource that has a correlated relationship with the density of invertebrate marine borers distribution and the borer punches the attached woods. Daniel (1998) more explaining that marine invertebrate, borers, whose ruining woods such as Celana sp (limpet), Styela plicata, and Mythilus sp (oyster). Those marine borers are commonly found at the wooden port and boat or cannoe.

Communities and fishers habit achoring their traditional boat or canoe in different distance and depth, and utilizing uncatorized quality of woods in the watering condition is raised consequences to demage those vehicles by marine borers and eventually appearing disadvantages. Widodo (2007) explaining that boat making plan using woods needs to cognize wood quality in order to avoid losses. Knowledge about woods quality and marine borers must be belonged by boat builder or local fishers. The knowledge has to be 


\section{International Journal of Science and Research (IJSR) \\ ISSN (Online): 2319-7064}

Index Copernicus Value (2013): 6.14 | Impact Factor (2015): 6.391

delivered to those people in according with understanding the important of knowlede in overcoming problems that could obstruct their works to avoid losses. It is revealed in the research report of Mulyono (1984) that knowledge of boat wood structures and canoes is very significant to the coastal community and fishers income level. Mastery of knowledge of coastal community and fishers about wood quality and marine invertebrates, borers, is very beneficial to increase their living standard.

Based on explaining above about the importance of wood quality in increasing coastal community living standard. Thereof, the aims of this research were (1) to know spesies of algae and marine invertebrates (borers) attaching to various boating woods in terms of depth, soaking distance from shoreline, (2) how the effect of boating woods, soaking depth, soaking distance from shoreline towards the marine borers density, and (3) Correlation between algae segmentation and marine borers density to kinds of damaged woods in terms of soaking depth 1 meter and 2 meters with distance 30 meters and 50 meters from the shoreline.

\section{Research Methods}

This research used experiment with factorial treatment model (cluster random design) and the treatment designs consisted of wood species, water depth, and distance of object to the shoreline. Based on treatment formula as (t-1) $(\mathrm{r}-1) \geq 15$ or $(16-1)(\mathrm{r}-1) \geq 15=15 \mathrm{r} \geq 15$, there were two treatmental replicants counting in order to gain research requirements, resulted $2 \times 15 \geq 15$ or $30 \geq 15$. The model has some factorial patterns, such as wood species x soaking depth x soaking distance to the shoreline. Model treatments are shown in the Picture 3.1 as follows.
Replication 1

Replication 2

\begin{tabular}{|l|}
\hline A. K1. J1 \\
\hline B. K1. J1 \\
\hline C. K1. J1 \\
\hline D. K1. J1 \\
\hline B. K2. J1 \\
\hline D. K2. J1 \\
\hline A. K2. J1 \\
\hline C. K2. J1 \\
\hline A. K2. J2 \\
\hline D. K2. J2 \\
\hline B. K2. J2 \\
\hline C. K2. J2 \\
\hline B. K1. J2 \\
\hline A. K1. J2 \\
\hline C. K1. J2 \\
\hline D. K1. J2 \\
\hline
\end{tabular}

\begin{tabular}{|l|}
\hline B. K1. J1 \\
\hline D. K1. J1 \\
\hline A. K1. J1 \\
\hline C. K1. J 1 \\
\hline A. K2. J1 \\
\hline C. K2. J1 \\
\hline B. K2. J1 \\
\hline D. K2. J1 \\
\hline B. K2. J2 \\
\hline D. K2. J2 \\
\hline A. K2. J2 \\
\hline C. K2. J2 \\
\hline D. K1. J2 \\
\hline A. K1. J2 \\
\hline B. K1. J2 \\
\hline C. K1. J2 \\
\hline
\end{tabular}

Where:

$\mathrm{A}=$ Calophyllum inophyllum Liin, $\mathrm{B}=$ Intsia amboinensis Thouars, $\mathrm{C}=$ Gmalina maluccana Backer, $\mathrm{D}=$ Agahtis alba Foxw), K1 = water depth at $1 \mathrm{~m}, \mathrm{~K} 2=$ water depth at $2 \mathrm{~m}$. $\mathrm{J} 1=$ Object distance to the shoreline at $30 \mathrm{~m}, \mathrm{~J} 2=$ Object distance to the shoreline at $50 \mathrm{~m}$.

Before soaking, those wood samples were smeared with white sheating substances in order to observe easily the algae sementation and marine borers that attached on its surface. Those woods sampels emerged into sea water colum as depth as 1 and 2 meters depth from sea surface with some iron ballasts in according with those samples are still stable. Each rope of the wood samples ropped with $40 \mathrm{~kg}$ ballast and soaked on the sea bottom surface as long as eight months since Januari 1, until August 1, 2010. Soaking wood samples sketch is drawn as following Figure 2.1. 


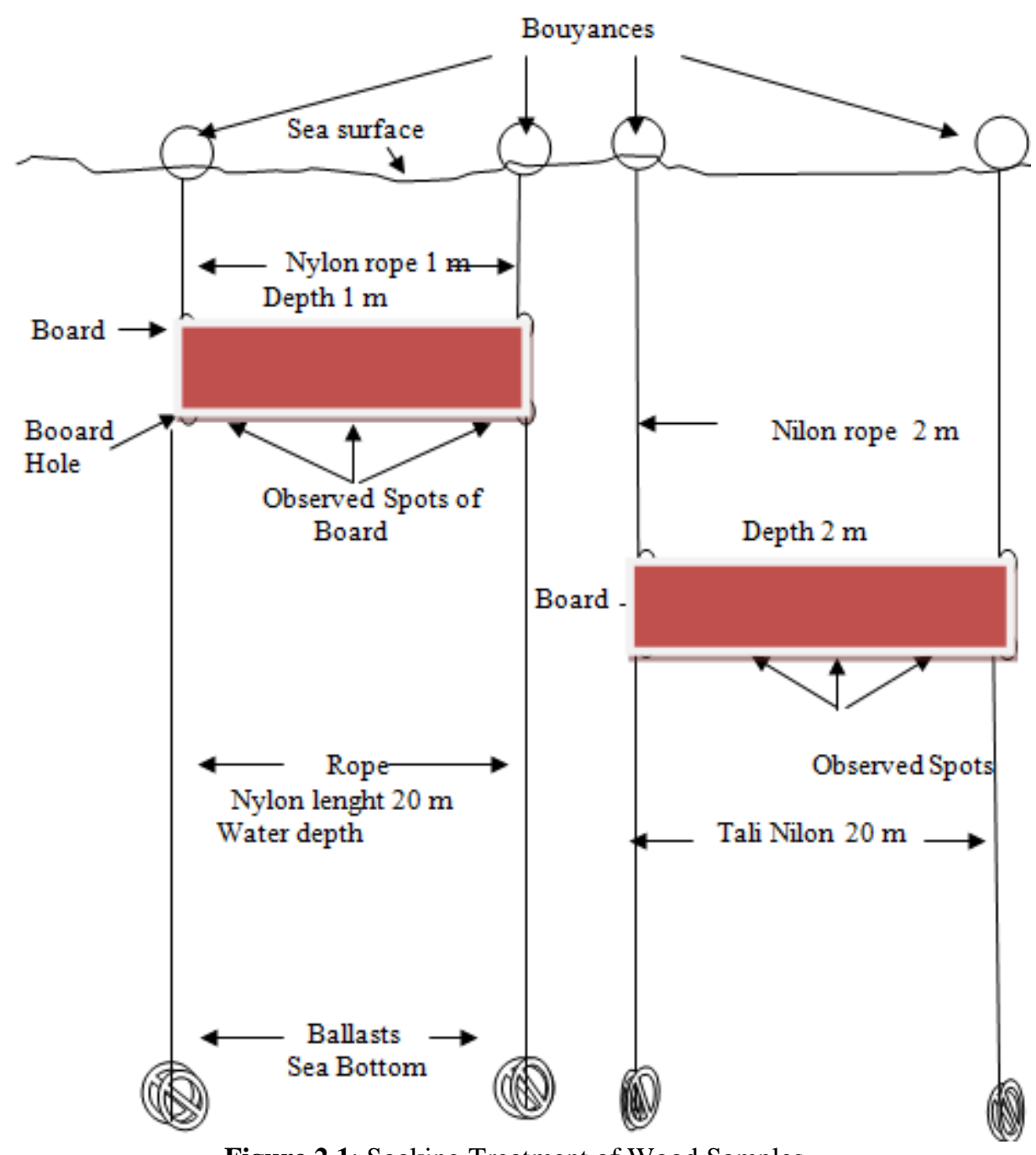

Figure 2.1: Soaking Treatment of Wood Samples

Cross-sectional areas of sampled woods that were mounted perpendicularly toward shorelines with 30 meters and 50 meters long and distance of each those samples horizontally were 600 meter long. Placing of those wood samples in the water were adjusted to the shore topography and the geographical condition of Ambon Island. Counting abundance index was based on Carles ,1985.

Relative Abundance $=\frac{\text { Found Species in the Sampling Areas }}{\text { All Species in the Sampling Areas }} \times 100$

Data was analyzed by using inferential statistic analysis. All collecting data were analyzied used double anova by Software SPSS 17 for Windows. Significance level was $\alpha$ 0.01 in replaying various proposed problems previously.

\section{Research Results}

Determining woods quality during soaking process was conducted through observing and analyzing data resulted as shown below.

\subsection{Species Alage and Cementation of the Algae Attached to the Treated Woods}

Research description of found algae was focused on alagae species and its cementation attached to the treated woods in soaking depth, both 1 meter and 2 meter water depth and at distance 30 and 50 meters long from shoreline, respectively. Identifying algae based on its morphological characteristics and specified salience according to its taxonomy level as shown in the following Table 3.1. 


\section{International Journal of Science and Research (IJSR) \\ ISSN (Online): 2319-7064}

Index Copernicus Value (2013): 6.14 | Impact Factor (2015): 6.391

Table 3.1: Species Algae Attaching on the Treated Woods at 1 and 2 meters Soaking Depth on both distances, 30 dan 50 meters long from Shoreline, respectively

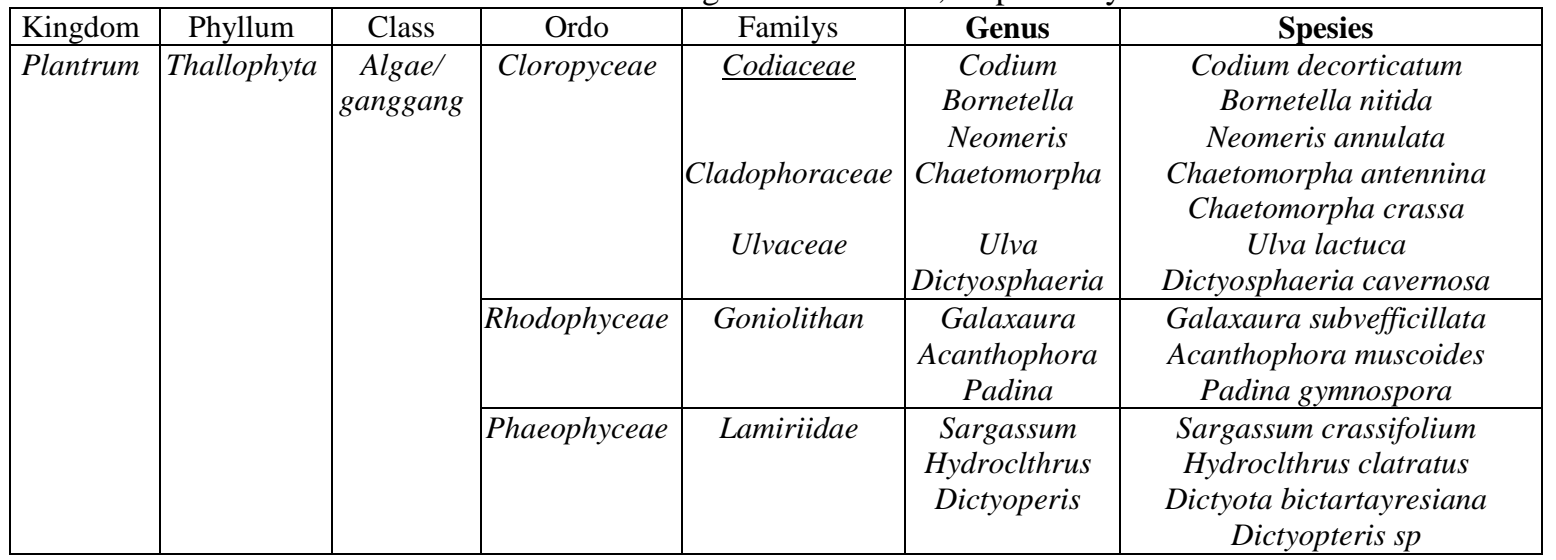

Identifying algae results as shown in Table 4.2 shows that some algae species attaching to treated woods as many as 14 species which is grouped in three strains such as green, red and brown. Alga strain green consists of ordo Clorophyceae, this ordo has 7 species such as Codium decorticatum, Bornetella nitida, Neomeris annulata, Chaetomorpha antennina, Ulva lactuca, Chaetomorpha crassa, Dictyosphaeria cavernosa; (2) algae strain red has an ordo Rhodophyceae that consists of three species namely Galaxaura subvefficillata, Acanthophora muscoides,
Padina gymnospora; and algae strain brown which comes from ordo Phaeophyceae that are 4 spesies including such as Sargassum crassifolium, Hydroclthrus clatratus, Hydroclathrus cancellatus, Dictyopteris sp.

Measurement of algae cementation in each treated woods was carried out using scientific caliper. The collected data then was analyzed to count its average for destrictivelystatistics as shown in the Table 3.2 as follows.

Table 3.2: Algae Cementation in Each Treated Woods.

\begin{tabular}{|c|c|c|c|c|c|}
\hline Distance & Depth & C. inophyllum Liin & I. amboinensis Thouars & G.maluccana Backer & A. alba Foxw \\
\hline \multirow{2}{*}{30} & 1 & $3.01 \mathrm{~cm}$ & $4.265 \mathrm{~cm}$ & $4.57 \mathrm{~cm}$ & $5.21 \mathrm{~cm}$ \\
\cline { 2 - 6 } & 2 & $0.835 \mathrm{~cm}$ & $1.11 \mathrm{~cm}$ & $1.70 \mathrm{~cm}$ & $2.27 \mathrm{~cm}$ \\
\hline \multirow{2}{*}{50} & 1 & $2.925 \mathrm{~cm}$ & $3.695 \mathrm{~cm}$ & $4.525 \mathrm{~cm}$ & $4.685 \mathrm{~cm}$ \\
\cline { 2 - 6 } & 2 & $0.795 \mathrm{~cm}$ & $1.03 \mathrm{~cm}$ & $1.32 \mathrm{~cm}$ & $1.83 \mathrm{~cm}$ \\
\hline Total & & $7.565 \mathrm{~cm}$ & $10.1 \mathrm{~cm}$ & $12.115 \mathrm{~cm}$ & $13.995 \mathrm{~cm}$ \\
\hline Average & & $1.891 \mathrm{~cm}$ & $2.525 \mathrm{~cm}$ & $3.028 \mathrm{~cm}$ & $3.498 \mathrm{~cm}$ \\
\hline
\end{tabular}

Table 3.2 above shows statistical-descriptive analysis of algae cementation that is obtained by average of all treated wood samples namely $C$. inophyllum Liin, I. amboinensis Thouars, G.maluccana Backer, and A. alba Foxw, are 1.891 $\mathrm{cm}, 2.525 \mathrm{~cm}$, (3) $3.028 \mathrm{~cm}$, and $3.498 \mathrm{~cm}$, respectively.

\subsection{Marine Borers}

Marine borers found attaching in the treated boards further were counted to all individus. All counted data were analyzed statistiscally in providing descriptive explaination. Those data classified into three main parts such as marine borers' species, variety index of marine borers, and abundance index of marine borers attaching to the treated woods. All species were classifying according to its taxonomy level as shown in the following table.

Table 3.3: Marine Borers Attaching to the Treated Wood Samples.

\begin{tabular}{|c|c|c|c|c|c|c|}
\hline Kingdom & Phyllum & Class & Ordo & Family & Genus & Spesies \\
\hline \multirow[t]{9}{*}{ Animal } & \multirow[t]{6}{*}{ Arthropoda } & \multirow[t]{6}{*}{ Crustacea } & Cirripedia & Lepadidae & Lepas & Lepas fascicularis \\
\hline & & & & & & Lepas hillil \\
\hline & & & & & & Lepas ansarifera \\
\hline & & & & & & Lepas pectinata \\
\hline & & & Sessilia & Balanidae & Balanus & Balanus balanus \\
\hline & & & Thoracica & Chthamalidae & Chatamalus & Chatamalus proteus \\
\hline & \multirow[t]{3}{*}{ Molusca } & Gastropoda & & Nacellidae & Cellana & Cellana tramoserica \\
\hline & & \multirow[t]{2}{*}{ Pelecypoda } & Pteriomorphia & Lyrosmatidae & Styela & Styela plicata \\
\hline & & & & Ostreoida & Crassostrea & Crassostrea virginica \\
\hline
\end{tabular}

Table 3.3 above shows that marine borers found at the treated woods such as first, Phyllum Arthropoda, Class Crustacea, Ordo Cirripedia, Familly Lepadidae dan Balaidae, Chthamalidae Genus: Lepas, Balanus, Chatamalu. The species are six species including Lepas fascicularis, Lepas hilil, Lepas ansarifera, Lepas pectinata, Balanus-balanus and Chatamalus proteus. Second, Phyllum Molusca, Class Gastropoda dan Pelecypoda, Ordo Pteriomorphia Familly Lyrosmatidae, Ostreoida, Genus Cellana, Styela, Crassostrea. There are three species namely

\section{Volume 5 Issue 6, June 2016 www.ijsr.net}




\section{International Journal of Science and Research (IJSR) \\ ISSN (Online): 2319-7064}

Index Copernicus Value (2013): 6.14 | Impact Factor (2015): 6.391

Cellana tramoserica, Styela plicata dan Crassostrea virginica.

\subsection{Marine Borers Abundance}

Counting of all marine borer individus attaching in each treated woods then analyzed to have its abundace average statistically that is described in the following Table 3.4.

Table 3.4 Marine Borers Abundance found attaching in each Treated Woods.

\begin{tabular}{|c|c|c|c|c|c|}
\hline Distance & Depth & $\begin{array}{c}\text { C. } \\
\text { inophyllum } \\
\text { Liin }\end{array}$ & $\begin{array}{c}\text { I. amboinensis } \\
\text { Thouars }\end{array}$ & $\begin{array}{c}\text { G.maluccana } \\
\text { Backer }\end{array}$ & $\begin{array}{c}\text { A. alba } \\
\text { Foxw }\end{array}$ \\
\hline 30 & 1 & 13.485 & 19.775 & 20.435 & 21.78 \\
\hline & 2 & 3.4 & 3.59 & 5.145 & 5.605 \\
\hline 50 & 1 & 8.46 & 12.535 & 12.353 & 14.425 \\
\hline & 2 & 0.42 & 2.07 & 2.55 & 2.76 \\
\hline Total & & 25.765 & 37.97 & 40.483 & 44.57 \\
\hline Average & & 6.441 & 9.492 & 10.120 & 11.142 \\
\hline
\end{tabular}

Table 3.4 above shows that marine borers found attaching in each treated woods have individual abundance as follows $C$. inophyllum Liin, I. amboinensis Thouars, G.maluccana Backer, A. alba Foxw are 6.441, 9.492, 10.120, 11.142, respectively. Average of marine borers founding in each treated woods of Table 4.8 above is describing in percentage (\%) such as C. inophyllum Liin (17.32\%), I. amboinensis Thouars (25.52\%), , G.maluccana Backer (27,21\%), A. alba Foxw $(29,95 \%)$.

\subsection{Variance Test of Algae Cementation}

Hypotethical testing to know woods species to algae cementation distance was conducted using varians analysis with significant level on $\alpha 0,01$. Hypotethical testing result is written in the following table.

Table 3: 5 Varians Analysis Summary of Woods Species, Soaking Distance, Soaking Depth Effects to Algae Cementations.

\begin{tabular}{|c|c|c|c|c|c|}
\hline Source & $\begin{array}{c}\text { Type III } \\
\text { Sum of } \\
\text { Squares }\end{array}$ & Df & $\begin{array}{c}\text { Mean } \\
\text { Square }\end{array}$ & F & Sig. \\
\hline Corrected Model & 73.807 & 15 & 4.920 & 730.652 & .000 \\
\hline Intercept & 239.531 & 1 & 239.531 & 35568.457 & .000 \\
\hline Woods & 11.405 & 1 & 3.802 & 564.512 & .000 \\
\hline Jarak & 0.586 & 1 & .586 & 87.002 & .000 \\
\hline Depth & 60.473 & 1 & 60.473 & 8979.676 & .000 \\
\hline Woods* Distance & .189 & 3 & .063 & 9.359 & .001 \\
\hline Woods*Depth & .974 & 3 & .325 & 48.212 & .000 \\
\hline Distance* Depth & .010 & 1 & .010 & 1.508 & 0.237 \\
\hline Woods*Distance*Depth & .171 & 3 & .057 & 8.446 & .001 \\
\hline Error & .108 & 16 & .007 & & \\
\hline Total & 313.446 & 32 & & & \\
\hline Corrected Total & 73.915 & 31 & & & \\
\hline
\end{tabular}

Result of hypotethical testing in the Table 3.5 above shows that woods species, soaking distance, soaking depth effects to algae cementations and their combination with significant level on $\alpha 0,01$. Description of all results are stated below.

\section{Effect of Wood Species to Algae Thickness}

The result of hypotethical testing shows that $F_{\text {count }}$ as 564.5112 with signicant $F_{\text {count }}$ is 0,000 . $\mathrm{P}$ value is $0,000<\alpha$ 0,01 . This means that null hypotethic is rejected and accepted research hypotethic which was stating that "there is an effect of wood species to algae cementation thickness. Therefore, woods species gives affecting siginificantly to the algae cementation. Furthermore, determining algae cementation differences based on woods species was conducted by LSD testing (Least Significance Difference) with its significant level on $\alpha 0,01$. Result of analysis is shown on Table 3.6 as follows.

Table 3.6: LSD Testing of Woods Species to Algae Thickness

\begin{tabular}{|c|c|c|c|}
\hline No. & Woods Species & Mean & Notation \\
\hline 1. & A. alba Foxw & 3,499 & a \\
\hline 2. & G.maluccana Backer & 3,029 & b \\
\hline 3. & I. amboinensis Thouars & 2,525 & c \\
\hline 4. & C. inophyllum Liin & 1,891 & d \\
\hline
\end{tabular}

Result of LSD Testing used for figuring differences between algae cementation thickness and woods species with significant level on $\alpha 0,01$ as shown in the Table 3.8 is described such as the thickness of algae cementation is $A$. alba Foxw with $3,499 \mathrm{~cm}$ and the lowest one is $C$. inophyllum Liin with $1,891 \mathrm{~cm}$. Farther, those woods species are different each others.

\section{Soaking Distance of Shoreline to Algae Thickness}

Hypotethical testing results that $F_{\text {count }}$ is 87.002 with significant $F_{\text {count }}$ is 0,000 . $\mathrm{P}$ value is $0,000<\alpha 0,01$. This means that null hypotethic (H0) is rejected and accepted reseach hypotethic. The research hypotethic stated that there was an effect of soaking distance of shoreline to algae cementation attaching to treated woods. Hence, Distance of woods soaking to shoreline is very significant to algae cementation. This relationship is shown that algae cementation in distance 30 meters long attached as thick as $2.871 \mathrm{~cm}$ than 50 meters long which attached as thich as $2.601 \mathrm{~cm}$.

\section{The Effect of Soaking Depth to Algae Cementation Thickness}

According to the hypothetical testing, results $\mathrm{F}_{\text {count }}$ value as big as 8979.676 with its significant $F_{\text {count }}$ as 0,000 and $P$ value $0,000<\alpha 0.01$, respectively. This result indicates that null hypotethic (H0) is rejected and received reseach hypotethic which was determined previously that there was an effect of soaking depth to algae cementation attaching to the treated woods. Furthermore, this result gives meaning soaking depth gives significant effect to algae cementation attaching to the treated woods. This relationship is supported by both evidence of the table above that the most thikness is found at the 1 meter depth and then second one 2 meter depth with $4.11 \mathrm{~cm}$ and $1.361 \mathrm{~cm}$, respectively.

4. Interacting Effects Between Woods Species and Soaking Distances of Shoreline to Algae Cementation Hypotethical test results show that $F_{\text {count }}$ is 9.359 and it is significantly on $\mathrm{F}_{\text {count }}$ as big as 0,001 with $\mathrm{P}$ value on $0,001<$ $\alpha 0,01$. This value means reject null hypotethic $(\mathrm{H} 0)$ and receive research hypotethic. Research hypotethic was 


\section{International Journal of Science and Research (IJSR) \\ ISSN (Online): 2319-7064 \\ Index Copernicus Value (2013): 6.14 | Impact Factor (2015): 6.391}

determined previously that there was an interacting effect between woods species and soaking distance of shoreline to the algae cementation attaching to the treated woods. It is indicating that interaction between woods species and soaking distance is influence significantly to algae cementation. For more evidence of this condition, there was conducted a LSD test to analyize the differentiation of algae cementing with its significant level on $\alpha=0,01$ as shown in the table 3.7 .

Table 3: 7 LSD Testing about interaction between Woods Species and Soaking Distance of Shoreline to Algae Cementation

\begin{tabular}{|l|c|c|l|}
\hline Woods Species & Distance & $\begin{array}{c}\text { Mea } \\
n\end{array}$ & $\begin{array}{l}\text { Notatio } \\
n\end{array}$ \\
\hline & 30 & 3.74 & \\
Agahtis alba Foxw & meters & 0 & $\mathrm{a}$ \\
\hline & 50 & 3.25 & \\
Agahtis alba Foxw & meters & 8 & $\mathrm{~b}$ \\
\hline & 30 & 3.13 & \\
Gmalina maluccana Backer & meters & 5 & $\mathrm{bc}$ \\
\hline & 50 & 2.92 & \\
Gmalina maluccana Backer & meters & 2 & $\mathrm{~cd}$ \\
\hline & 30 & 2.68 & \\
Intsia amboinensis Thouars & meters & 7 & $\mathrm{de}$ \\
\hline & 50 & 2.36 & \\
Intsia amboinensis Thouars & meters & 3 & $\mathrm{f}$ \\
\hline Calophyllum inophyllum & 50 & 1.86 & \\
Liin & meters & 0 & $\mathrm{~g}$ \\
\hline
\end{tabular}

LSD Test verifies the difference of algae cementation to the combination between woods species and soaking depth with significant level on $\alpha=0.01$ as shown at Table 3.3 above, can be explained in details as following. Firstly, algae cementation of A. alba Foxw at distance 30 meters long is $3.740 \mathrm{~cm}$ in thickness which is indicating more thickness than 50 meters long in distance $(3.258 \mathrm{~cm}$ in thickness). Secondly, algae cementation of $G$. maluccana Backer at distance 30 meters and 50 meters long are not different significantly, $3.135 \mathrm{~cm}$ and $2.922 \mathrm{~cm}$ in thickness, respectively. Thirdly, algae cementation of I. amboinensis Thouars at distance 30 meters (2.687 in thickness) is more thikness than 50 meters long at distance $(2.363 \mathrm{~cm}$ in thickness). Fourthly, algae cementation of $C$. inophyllum Liin, both 30 meters and 50 meters long at distance are not significantly, 1.922 and $1.860 \mathrm{~cm}$ in thickness, respectively. Fifthly, both soaking distance of shoreline to algae cementation on all treated woods are different each others. The most thickness algae cementation is on A. alba Foxw and the lowest one is G. maluccana Backer.

\section{Interacting Effect of Woods Species and Soaking Depth to Algae Cementation}

Hypotethical testing shows $F_{\text {count }}$ is on 48.212 with its significant $F_{\text {count }}$ on 0,000 and its $P$ value $=0,000<\alpha 0.01$. This means the null hypotethical is rejected and accepted research hypothetic that determining previously as there was an interacting effect between woods species and soaking depth of treated woods to algae cementation. Therefore, interacting between woods species and soaking depth of treated woods affects algae cementation.

Furthermore, in determining algae cementation differentiation based on combination effects between distance and soaking depth of treated woods then LSD test is used with significant level on $\alpha=0.01$ to show their differentiation value as shown on the following Table 3.8.

Table 3: 8 LSD Testing on Interaction between Woods Speceies and Soaking Depth of Treated Woods to Algae

\begin{tabular}{|c|c|c|c|} 
Cementation \\
\hline Woods Species & Depth & Mean & Notation \\
\hline A. alba Foxw & 1 meter & 4.948 & $\mathrm{a}$ \\
\hline G.maluccana Backer & 1 meter & 4.547 & $\mathrm{~b}$ \\
\hline I. amboinensis Thouars & 1 meter & 3.980 & $\mathrm{c}$ \\
\hline C. inophyllum Liin & 1 meter & 2.967 & $\mathrm{~d}$ \\
\hline A. alba Foxw & 2 meters & 2.050 & $\mathrm{e}$ \\
\hline G.maluccana Backer & 2 meters & 1.510 & $\mathrm{f}$ \\
\hline I. amboinensis Thouars & 2 meters & 1.070 & $\mathrm{~g}$ \\
\hline C. inophyllum Liin & 2 meters & 0.815 & $\mathrm{~g}$ \\
\hline
\end{tabular}

LSD test conducting to examine thick differences of algae cementation on the combination between woods species and soaking depth of treated woods with significant level at $\alpha$ 0,01 as pointed in the Table 3.8 above can be described as following. First, in 1 meter depth, the algae cementation of four treated woods are different each others. The most thickness is $A$. alba Foxw and the lowest one is $C$. inophyllum Liin. Second, in 2 meters depth, the algae cementation is found thickly on the G.maluccana Backer and thinlly on $C$. inophyllum Liin and there is not differences of algae cementation at I. amboinensis Thouars.

\section{Interacting Effect between Soaking Distance of Shoreline and Soaking Depth of Treated Woods to Algae Cementation}

Hypotethical testing results shows that $F_{\text {count }}$ is 1.508 and significantly at $\mathrm{F}_{\text {count }}=0,237$, while its $\mathrm{P}$ value $=0.237>\alpha$ 0.01 . This means that null hypotethic (H0) is accepted and research hypotethic is rejected. Null hypotethic was determined previously hat there was no interacting effect between soaking depth and soaking distance of shoreline to algae cementation. Hence, there is no interaction effect between those components, the advanced testing is not proceed.

\section{Interacting Among Woods Species, Soaking Distance to the shoreline and Soaking Depth of Treated Woods to Algae Cementation}

The result of hypotethical testing shows that Fcount value as big as 8.446 and it is significantly at signifikasi $\mathrm{F}_{\text {count }}=$ 0.001 while its $\mathrm{P}$ value $=0.001<\alpha 0.01$. It means that null hypotethic (H0) is rejected and accepted research hypotethic. Research hypotethic was proposed proviously that there was an interanction among woods species, soaking treate woods distancee, and its soaking depth to algae cementation. Thereof, there is a significant effect among those combination to the algae cementation. Furtermore, LSD testing was conducted to verify the effects differences among those combination to the algae cementation with significant level at $\alpha 0.01$ as figuring on the following Table 3.11 . 


\section{International Journal of Science and Research (IJSR) \\ ISSN (Online): 2319-7064}

Index Copernicus Value (2013): 6.14 | Impact Factor (2015): 6.391

Table 3: 11 LSD Testing Summery of Interaction Among Woods Species, Soaking Distance and Soaking Depth to the Algae Cementation

\begin{tabular}{|l|c|c|c|c|}
\hline \multicolumn{1}{|c|}{ Woods Species } & Distance & Depth & Mean & Notation \\
\hline A. alba Foxw & 30 meters & 1 meter & 5.21 & $\mathrm{a}$ \\
\hline A. alba Foxw & 50 meters & 1 meter & 4.69 & $\mathrm{~b}$ \\
\hline G.maluccana Backer & 30 meters & 1 meter & 4.57 & $\mathrm{bc}$ \\
\hline G.maluccana Backer & 50 meters & 1 meter & 4.53 & $\mathrm{~cd}$ \\
\hline I. amboinensis Thouars & 30 meters & 1 meter & 4.27 & $\mathrm{de}$ \\
\hline I. amboinensis Thouars & 50 meters & 1 meter & 3.69 & $\mathrm{f}$ \\
\hline C. inophyllum Liin & 30 meters & 1 meter & 3.01 & $\mathrm{~g}$ \\
\hline C. inophyllum Liin & 50 meters & 1 meter & 2.93 & $\mathrm{~g}$ \\
\hline A. alba Foxw & 30 meters & 2 meters & 2.27 & $\mathrm{~h}$ \\
\hline A. alba Foxw & 50 meters & 2 meters & 1.83 & $\mathrm{~h} \mathrm{i}$ \\
\hline G.maluccana Backer & 30 meters & 2 meters & 1.70 & $\mathrm{i}$ \\
\hline G.maluccana Backer & 50 meters & 2 meters & 1.32 & $\mathrm{j}$ \\
\hline I. amboinensis Thouars & 30 meters & 2 meters & 1.11 & $\mathrm{jk}$ \\
\hline I. amboinensis Thouars & 50 meters & 2 meters & 1.03 & $\mathrm{k}$ \\
\hline C. inophyllum Liin & 30 meters & 2 meters & 0.84 & $\mathrm{kl}$ \\
\hline C. inophyllum Liin & 50 meters & 2 meters & 0.80 & $\mathrm{kl}$ \\
\hline
\end{tabular}

The LSD test examining thickness differentiation of algae cementation in combaning among woods species, soaking distance of shoreline, and soaking treated woods depth is shown in Table 3.11 above. It is can be described as following. Firstly, algae cementation commonly on the merged woods in 2 meters depth both 30 and 50 meters of shoreline has thinner than the 1 meter depth. It is can be said that the deeper the thinner of alga cementation. Secondly, both soaking distance of treated woods, 30 and 50 meters long in both 1 and 2 meters depth have a huge tend that algae cementation happening to the $C$. inophyllum Liin is the thinnest than others and adversly the A. alba Foxw is the most thickness than others.

\section{Discussion}

Algae attaching to the treated woods shows different thickness of algae cementation. It is supposed there is a bearing related to the wood tissue structures that has extractive compounds. Structured tissues of treated woods have both soft and solid textures. The treated wood which is high quality commonly has solid textures of tissues, in this case such as $C$. inophyllum Liin and I. amboinensis Thouars. Those woods are having a good preservation in preventing and hampering algae distribution in the cementation form. Whilst, both G.maluccana Backer and A. alba Foxw have stiff textures of tissues and their tissues also have porous textures and less solid and however having less preservation and easible for distributing algae to form the cementation.

C. inophyllum Liin and I. amboinensis Thouars are having solid structures and hard tissues which are high quality woods. Wahyuid (2005) explained that physical characteristic of woods is related to its age and girth diameter that means that is older and older a tree, its texture is so solid and hard which indicates a high quality wood. Both $C$. inophyllum Liin and I. amboinensis Thouars have hardly physical textures and a good extractive compound. Explaining by Eeros (1995) that wood species that has a high preservation can protect itself durably from organism attacks. Jonson (1998) explained that not all woods species has durability properties and those properties depend on compunding extractive components contained in the wood's cell tussues. The extractive compound cointained in the wood's cell tissues based on woods species and the woods habitats.

Soaking distance of shorelines of treated woods has a significant effect to differences algae cementation. Both distances, 30 and 50 meters long, have different algae cementation thickness such as $2.871 \mathrm{~cm}$ and $2.601 \mathrm{~cm}$, respectively. This dissimilarity is supposed each soaking distance of shorelines has different physical and biological characteristics of the water, especially water current that flows organic particle for growing algae. Ebert and Russell (1998) explained that intertidal zone is a good enough place of activities for growing marine biotas, abandontly nutrients from coastal and land areas, getting closser to the depper zone, the nutrient getting less. The availability of nutrients itself is influenced by water flows especially algae fragments as a food resources for growing herbivorous biotas. Explaining by Hingsmith (1985) that algae distribution and needed particles for growing algae to the new location depends on the algae distance and water movement.

Resulting varians analysis towards soaking depth of treated woods shows a significant effect of algae cementation differeces. Advanced test reveals the most thickness algae cementation is in depth 1 meter $(4.11 \mathrm{~cm})$ than 2 meters depth $(1.361 \mathrm{~cm})$. This differentiation is inferred relating to the algae reproducing highly on treated woods at 1 meter depth than the orther one. Susanto (1989) explained photosynthesis process and algae growth are related to the sunlighting intensity. Nevertheles, the light propagating patterns into the water can be detained by particles of the water which are needed by algae. At the water surface, light intensity is accepted highly and reversly getting depth, the light getting low. Explaining by Putu (2009) that Clorophyceae algae grows fast in the highly intensity of sun such as intertidal areas. Jagtap et al., (1996), Rhodophyceae and Paeophyceae algae require lights intensity especially in the sub-tidal areas that the depth is getting depth, but those algae have much been found in the sub-tidal zone which still having sop in low tides.

Forming algae cementation on the both $C$. inophyllum Liin and I. amboinensis Thouars are so thin as result of available extra-active durability compouns in preventing and obstructing algae distribution and cementation. Coto (2005) reported that there is a relationship between wood tissue structures and its durability, fine and solid tissues has low water content that is categorized into qualified wood.

Distances and depths that do not show the physical water differences there will anable happening distribution to the new places and forming algae cementation on the treated woods. This is shown on the treatment distance and depth interaction happened to forming algae cementation in the both depth, 1 and 2 meters depth and both distance, 30 meters and 50 meters long of seashore. Explaining by Grove (2005) that distributing of various algae with its piece fragments (thallus) flowing by sea current in the pelagical areas into intertidal or sub-tidal areas that has rich nutrients enabling those algae grow quickly and the depth can not limit specific algae. Algae thickness at the treated woods is 


\section{International Journal of Science and Research (IJSR) \\ ISSN (Online): 2319-7064 \\ Index Copernicus Value (2013): 6.14 | Impact Factor (2015): 6.391}

caused by the structures of woods. Wahyu et al., (2006) explained that intrusion of water to the woods cell structures causes the wood stability getting low, hence the woods tend to be underwent changing and easily broken. Tuaputty (2009) explained that $C$. inophyllum Liin and I. amboinensis Thouars have solid textures, its cell tissues paralelly and solid, are hard wood structures, differ with the others wood which have rigid tissue, porously tissues and easy to be broken by attaching of algae as food resources. Made (2001) explained that there still a lot of woods species that have same tissues structures and can be used for boating wood and the important thing is its structures must be soft and strong. Sceffer et al., (2006) explained that there are still a lot of woods species that is not tested of durability yet, especially physical properties of woods tissue structures by undifinied characteristics and also unseen wood durability to marine bores.

Varians analysis of wood soaking depth in different distance and depth shows significant effect to the differences abundance of marine borers and advanced test to examine differences to display that the 1 meter depth is more abundance five times (4.8) than the 2 meter depth. There is a leaning that deeper and deeper of the water, the marine borers are getting less. Marine borers differences on depth is supposed relating to the availability of algae cementation, as food resources. Explaining by Michael (1995) that nutrient availability is highly determined by marine bores distribution and population in the water. Nutrient availability is very affected by the survival marine borers.

Each water depth has different typical topography, furthermore, species and amount of marine borers are also supposed different. Rocky (2007) stating that marine borers is easy to be found in significant amounts at the shorelines and getting more depth the invertebrates are getting less found. Physical and biological factors are important in determining the marine borers abundance. Physical factor such as temperature and sun light is important to determine borders where the invertebrates living and the biological factor such as predation and competition tends to make a border where the marine borers living.

Based on advanced test of soaking depth found that the soaking distance of shoreline 30 meters has higher abundance, 1.7 times than the second distance, 50 meters long. This abundance is inferred there is availability characteristics that getting closser to the shoreline, the food resources is abundantly. Susanto (2000) explained that every water has its own different character between intertidal and sub-tidal areas. In sub-tidal areas, amounts of species and population of the marine invertebrates is very limited, however the invertebrate with various species and population is highly can be found in intertidal zones.

Finding results according to varians analysis reveal different abundance of marine borers highly is affected significantly according to the advanced test that shows the highest marine borers abundance found in three treated woods namely $G$. maluccana Backer, I. amboinensis Thouars and A. alba Foxw and the lowest one is $C$. inophyllum Liin. This differences as a result of treated woods have different tissue structures, so that the durability properties in the water environment is different also to restrict and inhibit attaching the marine borers. Durability properties of the wood depend on the protection component in side of the wood tissue structures. Describing by Darrel (1987) that hard wood species has different durability as a result of living environments. This clears up the $C$. inophyllum Liin durability has a habitat in coastal areas and I. amboinensis Thouars lives in coastal forests tend better durability properties against marine borers abundance than the three other treated woods. Moreover, differences abundance and distribution of marine borers is highly related to physical and chemical water factors, food resource and algae. Begon and Harper (1986) explained that physical and chemical factors of sea water highly determine the availability of marine borers. The physical factors such as light, temperature, salinity, water current, and tides in intertidal areas have been adapted by marine invertebrates. The biological factors have been contributing in growing and surviving of marine oranisms. It has proved from varians analysis towards interaction of distance and depth that do not show an effect significantly at level $\alpha 0.01$ towards marine borers abundance. Marine borers are abundantly high found in the I. amboinensis Thouars and the three others treated woods are shown unsignificantly different each other. The lowest significantly effect found in C. inophyllum Liin.

In the 2 meters depth, marine borers abundance are found as greatly in the G. maluccana Backer and the A. alba Foxw is not different with others. Whilest the lowest abundance is found in the $C$. inophyllum Liin, however there is no difference abundance to I. amboinensis Thouars. The low abundance of marine borers finding in the $C$. inophyllum Liin is not significantly different with $I$. amboinensis Thouars at 2 meters depth, because nutrient availability is in limiting amounts. Describing by David (2002), distributing of marine borers is broad enough, finding in all sea zones with various substrate in either afloat or deeper areas Various marine borers can live co-existancely with the high abundance wherever the water condition is appropriate such as boats and ports. Made (2001) explained that there are still woods species having the same tissue structures and can be utilized for boating materials, the wood tissue structures are solid and strong as due. Sceffer et al., (2006) explaining that there are still many untested hard woods in term of their durability, especially physical properties of tissue structures with undifined characteristics, and they are not shown different durability towards marine borers.

Interacting between distance, depth and woods species do not influence the marine borers abundance. This is supposed there is a relating the invertebrates properties as sessil animals whos moves for feeding into new places, so that distance, depth and woods species is not able inhibit those organism movement to settle in the treated woods. According to analyzing result and observation in both depth, 1 and 2 meters depth, and both distances, 30 and 50 meters, is shown the availability marine borers settling and undisclosing differences of marine borers species. Yasuda et al., (1981) explaining that various marine borers are parasits and having right to occupy the same spaces together in settling and distributing in tropical seawaters without depending on distance and depth in all finding water zones. 


\section{International Journal of Science and Research (IJSR) \\ ISSN (Online): 2319-7064 \\ Index Copernicus Value (2013): 6.14 | Impact Factor (2015): 6.391}

Furtheromer, treated woods can have similarity to marine borres attacking with undifferent broken levels. It is assumed there is a cementation algae finding on interaction between distance and depth which do not show cementation affacted differences. Also it is caused by treated woods tissue structures are not different between both treated woods, A. alba Foxw and G. maluccana Backer. Some woods species such as Shorea acuminata Dyer, $G$. maluccana Backer and A. alba Foxw have similarity structures and broken holes in wood tissues causing by marine borers having relation to the woods tussue structures. Hence, wood tissue structures of $C$. inophyllum Liin is no difference with I. amboinensis Thouars. A. alba Foxw and G. maluccana Backer have tissue structures in tissue cells.

\section{Conclusion}

Algae species finding attached on treated woods in the Leihitu Sub-district Coastal Waters of Ambon Island are similar with the reporting of Grova (2005) stated that algae finding in the coastal water of Ambon Island consisted of Chlorophyceae 23 species, distributing in literal zones, especially tidal areas that still merged and sub-tidal zone; algae strain red Rhodophyceae 8 species and Paeophyceae 17 species distributing in the depth of $2 \mathrm{~m}-10 \mathrm{~m}$ at intertidal and sub-tidal zones.

Analyzing results reveal algae thickness related significantly to marine borers abundance, however, figures clearly the durability and broken of treated woods. Therefore, $C$. inophyllum Liin and I. amboinensis Thouars have durability toward against marine borers comparing with the two other treated woods. Puslitbang (2008) explained that attacks intensity of marine borers to woods species of genus Callophyllum sp as 45\%, Instisia sp $50 \%$, Gmelina sp 80 $\%$ dan Agithis sp 90\%. hence, the proper woods species for boating materials are $C$. inophyllum Liin and I. amboinensis Thouars that have a good durability of sea waters than the two other treated woods.

Differentiation of algae cementation point of view, the most thickness of algae cementation is found on A. alba Foxw and the thinesst one is $C$. inophyllum Liin. Soaking distances of shoreline have an influence significantly to the algae cementation differences, the most thickness $(2.871 \mathrm{~cm})$ is found on 30 meters long, the other is only 2.601 at 50 meters long. Soaking depth is significantly affected the differenting algae cementation, the most thickness is found on 1 meter depth $(4.361 \mathrm{~cm})$ and the other is on thickness $1.361 \mathrm{~cm}$ in 2 meters depth. There is a significant effect between woods species and soaking distance towards algae cementation. The algae cementation is more thickness at 30 meters long than 50 meters long on A. alba Foxw. Whilst, the G. maluccana Backer is found algae cemention no signifcantly on both soaking distance of shoreline, 30 meters and 50 meters. $I$. amboinensis Thouars, the algae cementation is found more thickness at 30 meters long than 50 meters. There is no significantly thickness of algae cementation in $C$. inophyllum Liin neither 30 meters nor 50 meters long to the shoreline.

Interacting effect of woods species and soaking depth is significantly towards the algae cementation differences. In 1 meter soaking depth, algae cementation happened to the four treated woods which are different each others. The thickness algae cementation happened in A. alba Foxw and the lowest one is $C$. inophyllum Liin. While in 2 meters soaking depth, algae cementation found as the thickess is $G$. maluccana Backer and the lowest one is $C$. inophyllum but there is no significant to $I$. amboinensis Thouars. Interaction of soaking distances and soaking depth is not significantly affected to algae cementation, causing by each algae species can distribute and grows in different depths and distances. Marine borers species found attaching to treated woods are Lepas fascicularis, Lepas hilil, Lepas ansarifera, Lepas pictinata. Balanus-balanus Chatamalus proteus, Cellana tramoserica, Styela plicata, Crassostrea virginica. Depth influcens to marine borers greatly significant, where 1 meter depth is higher than 2 meters depth.

\section{References}

[1] Begon \& Harper, 1986, Ekology, Individu, population And Communites. Blackwell Sceintific Publication.

[2] Balikbanda, (2006). Perencanaan Pembanggunan dan Pengembangan Smal Poor Di Beberapa Kabupaten. Ambon. BNS Bapedda Propinsi Maluku.

[3] Papenas, (2005), Penelitian dan Pengembangan Kehutanan. Bogor. Departemen Kehutanan.

[4] Chairil N Siregar, (2008), Analisis Potensi Daerah Pulau-Pulau Terpencil. Jurnal Sosioteknologi Edisi 13 Tahun 7, April 2008

[5] Coto, Z. (2005) Kepekaan Kayu terhadap Perubahan. Prosiding Seminar Nasional VIII. Mapeki. Tenggarong, 3-5 September 2005. pp A53

[6] David. S. Wethey (2002) Biogeography, Competition, and Microclimate: The Barnacle in New England. Department of Biological Sciences, University of South Carolina, Columbia, South Carolina 29208

[7] David S. Wethey, (2002). Georaphyc Limits And Local Zonation: The Barnachles Sembilanus (Balanus) And Chthamalus In New England Department ofBiology and Marine Science Program, University ofSouzh Carolina, Columbia, SC 29208. Reference: Biol. Bull. 165: 330â€"341.

[8] Ebert and Russell. (1988). Latitudinal variation in size structure of the west coast purple sea urchin: a correlation with headlands. Limnology and Oceanography 33:286-294

[9] George Kunu, 2005, Penilaian FAO Mengenai Permintaan dan Penawaran (penyediaan Kayu di Indonesia. UNOHCA

[10] Grova. S. Berung dkk (2005) Study on the Seaweek of Ambon Island Indonesia. Costa Marine Science. Universitty Pattimura-Ambon.

[11] Hasan. Tuaputy, (2008 ), Studi Kualitas Kayu dan Penggerek Laut di Perairan Pulau Ambon Jurnal Bioedukasi. Biologi dan Pembelajaran. Universitas Jember. Vol IV N0 2. Oktober 2008.

[12] Hasan Tuaputty, (2009), Pengetahuan Masyarakat Nelayan Tentang Kualitas Kayu Pembuatan Perahu Di Kecamatan Leihitu Pulau Ambon. Seminar Nasional 7 Mei 2009 Universitas Pattimura Ambon.

[13] Hasan Tuaputty, (2008 b). Invertebrata Laut dan Pembelajaran Biologi. Seminar Guru-Guru Kota Malang. SMA Nehgeri 9. Malang.

\section{Volume 5 Issue 6, June 2016 www.ijsr.net}




\section{International Journal of Science and Research (IJSR) \\ ISSN (Online): 2319-7064}

Index Copernicus Value (2013): 6.14 | Impact Factor (2015): 6.391

[14] Mat Supply, 2007. Sifat-Sifat Kayu dan Penggunaannya. Jakarta Sumber : Depertemen Kehutanan RI

[15] Mada Sudana, (2001),Ketergantungan Masyarakat Dayak Terhadap Hutan Disekitar Taman Nasional Kayang Mentarang. Penelitian di COFOR dan sebelumnya di WWF. Kalimantan Timur. Dicetak SMK Grafika Desa Putera Indonesia.

[16] Michael. P. (1995), Metode Ekologi Penelitian Ladang Dan Laboratorium. Proyek Pegembangan Perguruan Tinggi. Derektorat Perguruan Tiinggi. Jakarta Suatu Pendekatan Biologi Laut. . Gramedia. Jakarta

[17] Mulyano, (1984) . Nelayan dan Kemiskinan; Study Ekonomi Antropologi di Dua Desa Pantai. Jakarta. Diterbitkan atas kerjasama Yayasan Aqro Ekonomika. Penerbit CV. Rajawali,

[18] Nicholas , (1987). Wood Deterioration and its Prevention by Preservative Tretment. Copyright@. University Press.

[19] Putu Sarigana Utami, (2009). Clorophyta (Ganggang Hijau). www. com.Ni.Lu.

[20] Priyanto Rahardjo, 2003. Nalayan Nusantara Sebuah Filsafat Kehidupan. ITB Bogor. Fakultas Sains. TJL. P26600002.

[21] Puslitbang BSN, (2008), Standardisasi Kayu. Puslitbang untuk kegiatan penelitian, pendidikan, dan pengembangan standar. Pusat Penelitian dan Pengembangan Hasil Hutan, Bogor

[22] Sceffer dkk, (2006), Natural resistence of wood and Deterioration. Centeral American and Education. Tropical Wood.

[23] Syarifudin Tualeka, (2005). Analisis pemanfaatan sumberdaya hayati pesisir dan upaya pengelolaan I pulau osi. Kebupaten Seram Bagian Barat. Pasca Perikanan dan Ilmu Kelautan. Universitas Pattimura.

[24] Stephen Tindle, (2003). Biological Sciences, University of South Alabama, Mobile, AL 36688, USA.

b Department of Biology, University of Richmond,
University of Richmond, Richmond, VA 23173, USA Received 23 July 2003; Revised 30 September 2003; accepted 10 October 2003. Available online 3 December 2003. file:///D:/volder Cirripedia/B.1.htm

[25] Sheppard, C., A. Price dan C. Roberts (1996), Marine ecology of the Arabian Region. Patterns and processes in extreme tropical environment. Academic Press, Harcourt Brace Johanovich, Publisher. London. p. 141160.

[26] Sitania, G. 1998. Mengenal lebih dekat jenis lamun (Enhalus acoroides Linnaeus f.) Royle. Warta Konservasi Lahan Basah Volume 7 No. 2,

[27]Smeru, 2001). Pentingnya Tata Ruang dalam Pembangunan Wilayah Pesisir. Sumber : Majalah Demersal Departemen Kelautan dan Perikanan Republik Indonesia

[28] Sotomo, (1998), Pola Rambatan Cahaya di Laut. LIPI. Pusat Penelitian dan Oseanologi. Penelitian dan Pengembangan Sumberdaya Laut-Ambon

[29] Sjostrom, (1995). Kimia Kayu. Dasar dan Penggunaan. Gadjamada University. Edisi Kedua. Fakultas Kehutanan. Universitas Gadja Mada. Yokykarta

[30] Slamet, (2000). Meningkatkan Partisispai masyarakat dalam pembanggunan perdesaan. Interaksi No 1 Jakarta.

[31] Wahyu Dwianto dan Sri Nugroho Marsoem, (2008) Review of Researches on Natural Factors Affecting the Physical and Mechanical Properties of Indonesian Wood. J. Tropical Wood Science and Technology Vol. 6 No. 2.

[32] Wahyudi, (2005) . Effect of Stem Diameter Size on Qualities of Eight Year-Old Bass wood Planted in Darmaga Area. Prosiding Seminar Nasional VIII Mapeki. Tenggarong, pp A115.

[33] Yasuda, and Kenji Hibino (1981). Studies on the effect on marine organisms of the warm water effluent from a nuclear plant. -Relation between the distribution of the acorn barnacles and the warm water effluent in Uchiura Bay-. Marine Fouling.

\section{Research in Pictures}

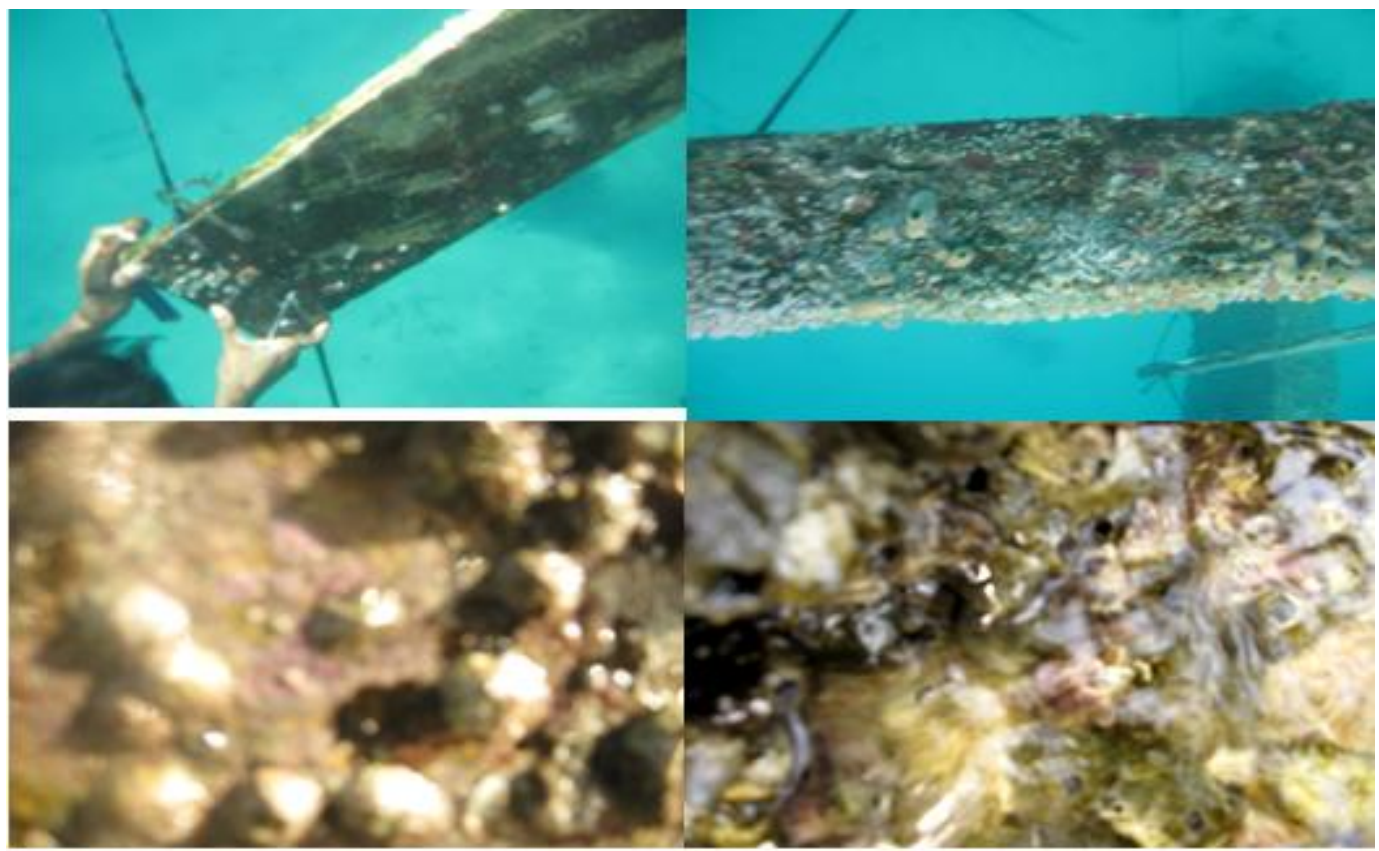

Animal wood Destroyer Picture

Volume 5 Issue 6, June 2016 www.ijsr.net

Licensed Under Creative Commons Attribution CC BY 


\section{International Journal of Science and Research (IJSR)}

ISSN (Online): 2319-7064

Index Copernicus Value (2013): 6.14 | Impact Factor (2015): 6.391
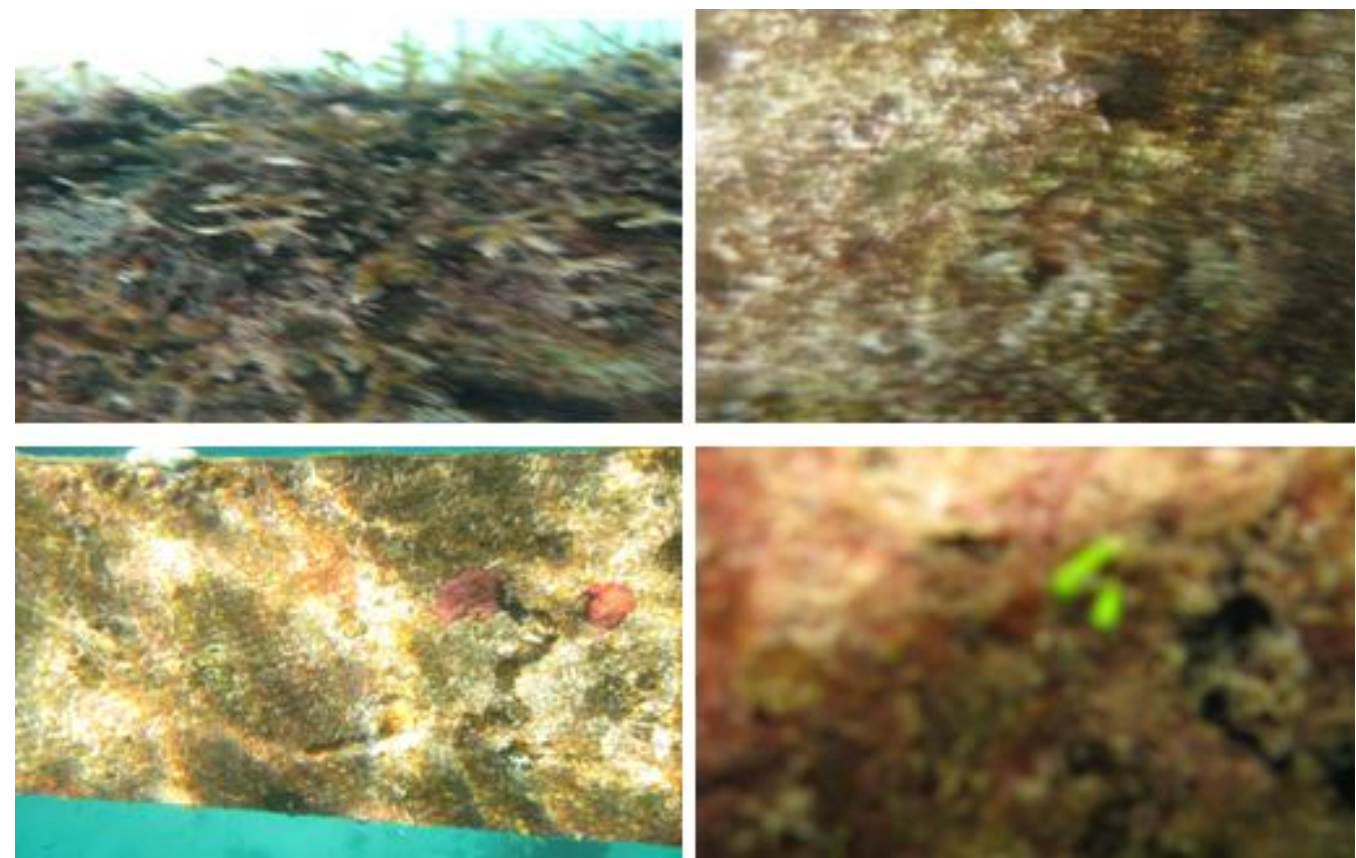

Thickness Algae On Wood Type Picture

Volume 5 Issue 6, June 2016 www.ijsr.net

Licensed Under Creative Commons Attribution CC BY 